\title{
Workplace Development as Part of Broad-based Innovation Policy: Exploiting and Exploring Three Types of Knowledge
}

\section{Tuomo Alasoini}

Director, Tekes - Finnish Funding Agency for Technology and Innovation, Adjunct Professor (Sociology), University of Helsinki, Finland

\begin{abstract}
This paper looks at the possibilities that a broad-based innovation policy contained by the national innovation strategy recently adopted in Finland opens up for the promotion of workplace innovations and examines the types of knowledge needed in workplace development. The author highlights the interconnections between workplace development and the prerequisites of both economic growth and the preservation of the Finnish welfare state. The paper also aims to explain why, in addition to the productivity of work, improving the quality of working life should feature as an increasingly important aim in the innovation policy of the future. An argument for the need of three types of knowledge in workplace development - design knowledge, process knowledge and dissemination knowledge - is made, together with an overview on new developments in each of those three domains. In conclusion, the author demonstrates how problems in the productivity of work and the quality of working life can be simultaneously tackled with at work organization level through two kinds of development approaches.
\end{abstract}

\section{KEY WORDS}

Innovation policy / productivity / quality of working life / workplace development / workplace innovation.

\section{Introduction}

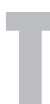

here is more talk about innovations in Europe today than ever before. A typical viewpoint put forward in the discussions is that the best way for Europe to succeed in the global economy is through forming a home base for active generation of product, service and business management innovations. The capacity to produce innovations particularly in the high-skill, high-tech segments of the economy is a central means through which Europe will be able to maintain its comparative advantage on the global scale (e.g. Storrie \& Ward 2007).

In recent years, Finland has gained reputation as one of the few countries, which has adopted the concept of 'national innovation system' as a guiding principle for its science and technology policy (Gergils 2005; Miettinen 2002). Until the early 2000s, however, the Finnish policy approach could be characterized, though 'systematic', as 'narrow' in the sense that its focus was firmly on technological innovations, it concentrated on advances in certain key branches and technologies, and it promoted innovation activity mainly by funding leading-edge firms and top universities and research institutes. In 2007, Prime Minister Vanhanen's Government launched the preparation of a national innovation 
strategy for Finland. The strategy, completed in 2008, is based on the idea that the focus of innovation policy should be shifted increasingly to demand and user-driven innovations and the promotion of non-technological innovations (Aho et al. 2008).

According to the strategy, also workplace development should be closely integrated as part of innovation policy planning and implementation in the future, sufficient financial resources for the promotion of workplace innovations should be ensured, and new methods for spreading workplace innovations should be extensively developed. In this respect, the new strategy could be considered an important milestone in Finland. Even though Finland has been among the top countries in Europe regarding investments in this area in recent years (Alasoini 2009; Brödner \& Latniak 2003; Gustavsen 2007), it was only in the new strategy that the promotion of workplace innovation became a generally recognised sector within mainstream innovation policy.

The increase in workplace development activities that started in the 1980s has been promoted by several factors in Finland. One such factor has been Finland's long tradition in both bipartite cooperation between employer and employee organizations, and tripartite cooperation between labour market organizations and government. In the aftermath of the deep recession that plagued Finland in the early 1990s, employer and employee organizations were well prepared to expand their cooperation with government into workplace development. Another contributing factor has been the upsurge, beginning in the early 1980s, in working life research and, specifically, the rise of actionoriented research on working life in universities and research institutes. This was a result of improved research financing opportunities, as well as being due to the culmination of problems in work ability, early retirement and job satisfaction, as well as the emergence of new approaches. These new approaches included, for example, participatory action research, socio-technical systems design, organisation development (OD), developmental work research, and process management.

The first government-funded programmes to focus exclusively on promoting workplace change and innovation in Finland began in 1993 and 1996, with the launch of the National Productivity Programme and the Finnish Workplace Development Programme (TYKE). The first programme was initiated by labour market organizations, the second by the Ministry of Labour. The Ministry of Labour coordinated both programmes, in which social partners were also closely involved. In 2004, the two programmes were combined under a new seven-year 'umbrella', titled the Finnish Workplace Development Programme (TYKES). In 1996-2010, over 1800 workplace development projects were funded through the programmes. Unlike in many other countries, the programmes were targeted not only at businesses, but also at the public sector. In the 1990s and 2000s, some other programmes and projects funded by the Ministry of Social Affairs and Health, the Ministry of Education, the Finnish Institute of Occupational Health and the European Social Fund have also focused on working life development.

The TYKE and TYKES programmes funded considerably large development projects, lasting typically from one to three years, which not so much aimed at 'quick fixes', but which were intended to pave the way for long-term development cooperation between management and personnel. The programmes left a lot of leeway to workplaces for setting project goals and implementation. The most typical aims of the projects were to improve work processes, forms of work organization, working methods, supervisory work and human resource management (HRM) practices. Usually, development groups were established to enable the implementation of the project on the shop floor level. In most cases, analyses and chartings of different kinds were carried out during the course 
of the project, for example, at the starting phase to provide basic information for development activities and at the concluding phase in the evaluation of project results. Typical methods used in the projects included also interviews, coaching, process consulting, team training, action research, process descriptions and process flow analyses. All in all, the methods used in the projects varied considerably, depending on the goals of the projects and the expertise of the consultants and researchers participating in the projects (Alasoini et al. 2005; Arnkil 2008).

As part of the implementation of the new innovation strategy, the TYKES programme was transferred to Tekes, the Finnish Funding Agency for Technology and Innovation, in 2008. Founded in 1983, Tekes is the largest public financier of research and R\&D activities in Finland. In recent years, the scope of its operations has been expanded from technology to innovation in a more general sense. In 2008, another adjustment was made in the legislation concerning Tekes, as the task of the organization was expanded to cover 'innovative research and development of working life' as well. At the same time, increasing productivity and the quality of working life (QWL) were included in the goals of its operations.

In an outside expert assessment of the Finnish innovation system that was carried out in 2008-09, the basic ambition of 'broad-based innovation policy' contained by the strategy was welcomed but the concept was also deemed vague in content (Veugelers et al. 2009). Seen from the history of workplace development in Finland, the new concept opens up new possibilities for increasing the social effectiveness of workplace development activities by making it easier for companies to launch comprehensive projects for the development of their operations. For example, it is now possible for Tekes to grant companies funding for $R \& D$ projects, which at the same time aim at renewals in their products and services, processes, work organization, management and personnel. On the other hand, owing to the fuzziness of the new concept, it also includes significant sources of potential tension. This tension boils down to two aspects, in particular, that have formed the value basis of the 'Finnish model for workplace development', as represented by the workplace development programmes, but that have so far been largely ignored in Finnish mainstream innovation policy (Alasoini 2009): firstly, workplaces should be developed in a way conducive to simultaneous, and mutually supporting, improvements in operational performance and QWL. Secondly, cooperation between management and personnel in development is necessary, because in this way it is possible to utilize versatile expertise in the planning and implementation of new solutions and to create shared understanding and acceptance based on the decisions that will be made.

Underlying these two aspects has been a constructive view on workplace innovations. According to this view, the concept of 'workplace innovation' is not limited to the adoption of a ready-made set of 'high-performance work practices'. The concept refers to collaboratively constructed changes in a company's organizational and HRM practices that lead to simultaneous improvements in operational performance (e.g. work productivity, product quality, process flow) and QWL (e.g. employees' opportunities for development and exerting influence at work, employee well-being at work) and that also support other types of innovation. The last part of the description is based on the view that different types of innovation at the company level are usually interwoven with each other, containing significant complementaries (Breshanan et al. 2002; Laursen \& Foss 2003; Whittington et al. 1999).

This paper examines three types of knowledge that are needed in workplace development to overcome this tension and reinforce the position of workplace development as an integral part of the new innovation policy approach. The views presented 
below are mostly based on the author's long involvement in workplace development programmes in Finland, supplemented with a review of the literature. The article is based on the conception that the significance of QWL as a national competitive factor is increasing in Finland. Based on experiences from Finland, the article considers how productivity and QWL can be promoted simultaneously in a situation where a skewed age structure and a decreasing supply of workforce threaten to shake the foundation of the entire welfare state. The question is particularly acute in Finland, where the oldage dependency ratio (the number of those aged 65 or more compared to the number of 15 to 64-year-olds) will deteriorate rapidly in the next few years and is predicted to be the highest among EU countries sometime in the 2020s (http://www.euphix.org/ object_document/o5117n27112.html, read 14 February 2011). At the same time, Finland could also be considered as an interesting reference point for many other countries as a forerunner of an ambitious innovation approach, in which a special emphasis is laid on workplace innovations as well.

\section{Good productivity and quality of working life as prerequisites of the Finnish welfare state}

The economic well-being of a nation can be presented as a function of two factors: the ratio of gross national product (GNP) to the number of working hours and the ratio of working hours to the amount of population. The first factor (GNP/working hours) describes the productivity of work, and the second factor (working hours/population) describes the participation of population in working life and the average working times.

It is not realistic to presume that the average working times would increase in Finland in the future. Alongside work, Finns today place an increasing value on family life and free time (Lehto \& Sutela 2009). Also, the proportion of people performing parttime work is small in Finland (9\% in 2008), which further limits the opportunities to increase average working times. The maintenance of economic well-being in Finland thus depends primarily on work productivity and the population's rate of participation in working life.

Jalava and Pohjola (2008) have stated that because in the next few years the amount of labour input can no longer grow in Finland due to the change in age structure, any increase in the standard of living must thus result from an increase in work productivity. According to them, a rise of 0.5 percentage points in the annual growth rate of work productivity compared to the current growth rate would, in a period of a few years, produce a higher standard of living than the creation of 100000 jobs. Means of increasing the productivity of work include investments in human capital, investments in machinery, equipment and infrastructure and technological development, such as the adoption of new products, services and operating methods. Jalava and Pohjola find that as the economy becomes increasingly knowledge-intensive, the significance of technology for growth in productivity - and consequently for growth in economy itself - is further emphasized. Information and communication technologies and the new operating methods enabled by them hold a key position.

Three remarks can be made regarding Jalava and Pohjola's perceptions. First, even though relatively slight improvements in productivity growth can produce a significant impact on the standard of living, it is not self-evident that a constant increase of 0.5 
percentage points in the annual growth rate of work productivity, as cited by Jalava and Pohjola, would be easily attainable. In fact, what we find is that even though work productivity growth in Finnish industry has been relatively fast in recent years, the overall growth rate shows a clear downturn trend since the mid-1990s, owing to the fact that growth has markedly slowed down in many service industries (Figure 1). As the Finnish economy is becoming increasingly service-oriented, relying on the notion that future economic growth could be ensured by growth in productivity alone would be risky.

Figure I: Average annual work productivity growth in Finland in 1976-2008,\% (source: Pasanen 20 I0)
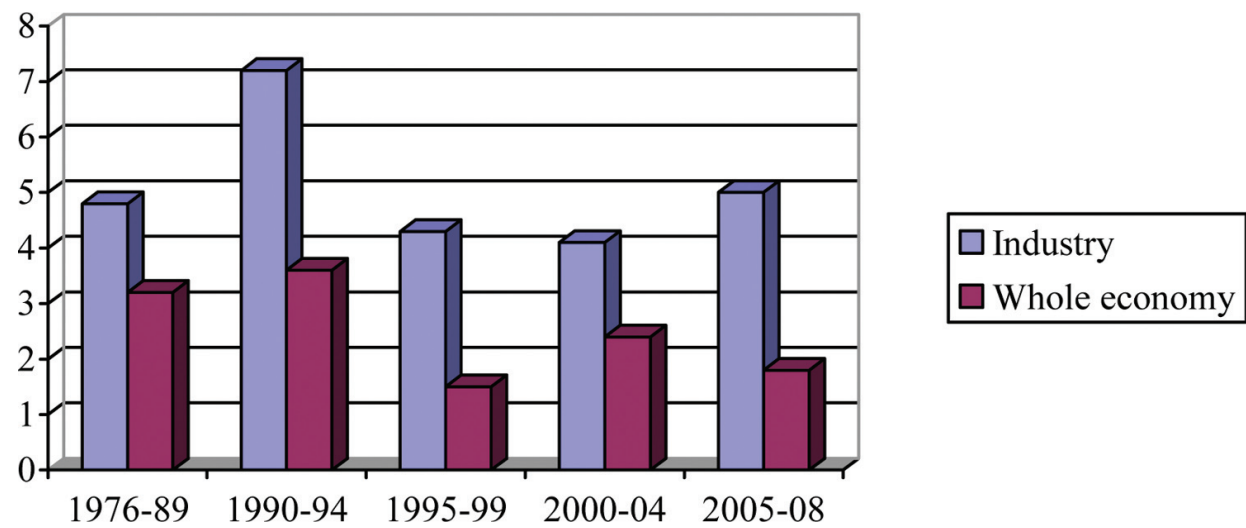

Secondly, as stated above, the supply of workforce in Finland is decreasing due to skewed age structure. This means that rise in the standard of living is, in the future, based on growth in work productivity alone. This does not mean, however, that the rate at which the supply of workforce is decreasing would not directly affect the potential for continuing to increase the standard of living. Development in the rate of participation in working life will thus continue to have an impact, just like it has done until now, on the economic potential for maintaining well-being.

The third remark concerns the fact that a high rate of participation in working life is in itself one factor that legitimizes the welfare state. If, in the future, we were to focus single-mindedly on generating productivity growth in order to maintain the welfare state, how could we be sure that the increasingly small amount of people doing increasingly high-productivity jobs would still be willing to cover the cost for making publically-supported welfare services widely and affordably available to the whole population?

An important way to prevent - or more aptly to slow down - the reduction in labour input now discernible in the horizon would be to extend careers beyond current retirement age. For the purposes of economic growth, extending careers beyond retirement age is more important than getting people to join the workforce at an earlier age. Mainly, this is down to two reasons.

First, as the economy becomes increasingly knowledge-intensive, it is not realistic to presume that the average duration of young people's education and training could be essentially shortened. In fact, to increase productivity, we are more likely to need even greater investments in human capital, which is likely to increase pressures in the oppo- 
site direction. Second, the positive effects of extending the careers of ageing workers are more significant, as in Finland the older age groups are far more populous. Surveys (e.g. Kauppinen et al. 2009; Tuominen et al. 2005) have shown that the qualitative characteristics of working life associated with the work environment, working hours, leadership and management, the atmosphere and social relations in the workplace, and the content of work emerge among the most significant motivation factors when people consider the option of extending their careers.

The development of labour force participation rates of older age groups in Finland during the last 20 years is, in fact, impressive. The positive trend shown in Figure 2 is due to many intertwining factors. It demonstrates that it has been possible to increase the participation of older age groups in working life and there still exist much room for improvement through further improvements in QWL, among others.

Figure 2: Labour force participation in Finland among older age groups in 1990-20 10,\% (source: Finnish Labour Review, various issues)

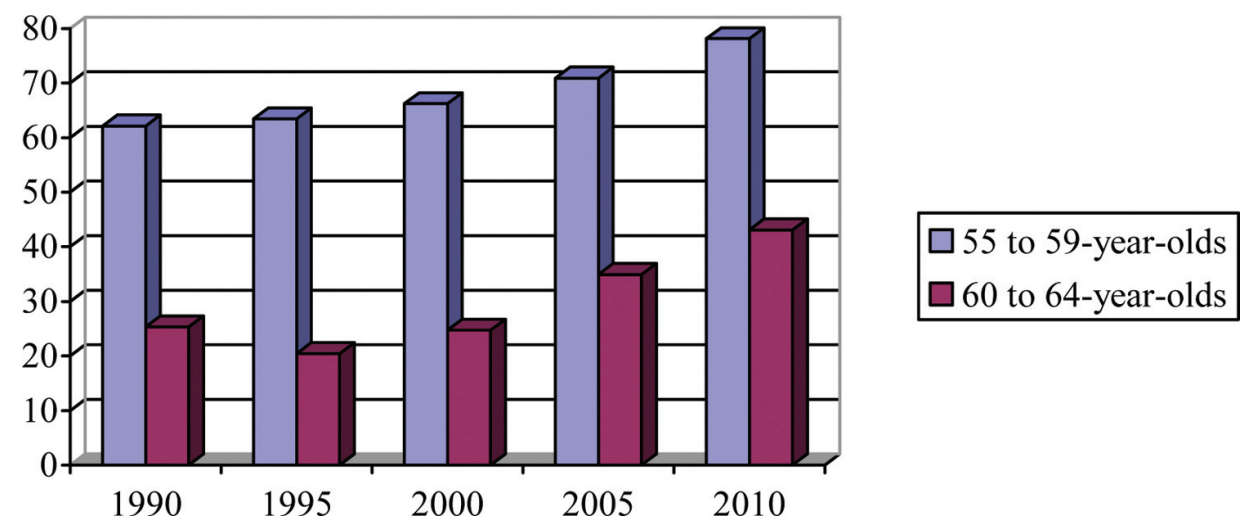

From a socio-political viewpoint, it is thus worthwhile to look for methods that have a simultaneous impact on the two central factors to economic growth, i.e. the productivity of work and the amount of labour input (in practice, the amount of workforce). The amount of workforce can be impacted positively by improving QWL (which of course is not the only way). QWL has direct positive effects on the prerequisites of economic growth: it is possible to extend the careers of ageing workers by improving QWL, as stated earlier. QWL can also have indirect positive effects on the prerequisites of economic growth which are mediated through growth in productivity, as QWL is an important prerequisite and motivation factor for people to perform their work more efficiently.

\section{Different strategies to promote workplace innovation}

It is possible to make a distinction between different types of policy approaches in the promotion of workplace innovation. On the most general level, we can talk of 'hard' and 'soft' forms of regulation. The former concept refers to legislative intervention. Soft reg- 
ulation, in turn, refers to non-binding, persuasive policy intervention (Trubek \& Trubek 2005). Deregulation can be regarded as the third main approach. Hard and soft regulation can be further divided into direct and indirect forms (Table 1).

Table I Policy options in the promotion of workplace innovation

\begin{tabular}{|c|c|c|c|}
\hline \multicolumn{2}{|c|}{$\begin{array}{c}\text { Hard/indirect regulation } \\
\text { legislation which focuses indirectly on } \\
\text { workplace innovation through changes in } \\
\text { some other policy area (e.g. product market } \\
\text { and labour market) }\end{array}$} & \multicolumn{2}{|c|}{$\begin{array}{c}\text { Hard/direct regulation } \\
\text { legislation which focuses directly on } \\
\text { workplace innovation (e.g. organizational } \\
\text { and HRM practices) }\end{array}$} \\
\hline $\begin{array}{l}\text { Soft/indirect regulation } \\
\text { general policy frameworks } \\
\text { and recommendations }\end{array}$ & \multicolumn{2}{|c|}{$\begin{array}{l}\text { Soft/intermediate-stage regulation } \\
\text { information on 'best } \\
\text { practices', and training and } \\
\text { education to managers and } \\
\text { employees }\end{array}$} & $\begin{array}{c}\text { Soft/direct regulation } \\
\text { advisory and consulting } \\
\text { services, benchmarking tools, } \\
\text { and grants and subsidies to } \\
\text { companies }\end{array}$ \\
\hline \multicolumn{4}{|c|}{ Deregulation } \\
\hline
\end{tabular}

The use of direct legislative intervention in the promotion of workplace innovation is rare. What we find, instead, is a great variety of soft forms of regulation (Alasoini 2009). A soft approach can be a useful policy option, especially in situations where the objects for change (companies) are heterogeneous; processes leading to desired changes (workplace innovations) can take different shapes; and means used in the promotion of changes (the introduction of new organizational and management practices) are of a sensitive nature.

Viability of the different policy options in Table 1 is dependent on what are the main reasons for the low level of workplace innovation in companies. Indirect forms of soft regulation may be enough, if it is solely a matter of lack of information. Intermediate-stage forms are needed in cases where a company lacks information or competence. If the major obstacle is in the motivational area (e.g. lack of pressure on the part of customers, competitors or any other stakeholder groups) or related to the high level of risk of innovating (e.g. long pay-back times of the investments made in workplace innovation, volatility of the environment or possible leaks in the actions taken), direct forms of soft regulation, combined with indirect forms of hard regulation, may be required.

A study by Business Decisions Limited (2002) on the obstacles to wider diffusion of new team-based forms of work organization that was carried out in $10 \mathrm{EU}$ countries in the early 2000s provides useful information on the most common apparent and underlying factors for the low level of workplace innovation in Europe. Among the companies that did not apply new forms of work organization as defined in the study, the biggest obstacles concerned motivational factors, i.e. new forms of work organization were not needed to meet customers' needs or did not fit the company's culture or strategy. Motivational factors were also mentioned as the main reason for problems that emerged during the implementation phase among the users of new forms of work organization, while also factors related to lack of competence played a role. The study gives strong support to a view that in most cases effective promotion of workplace innovation would 
call for more direct means than providing solely general policy guidelines, information, or training and education. A Finnish study that was made afterwards gives similar results (Ylöstalo 2005). In Finland, too, the two most important reasons for not applying team-based work patterns were their incompatibility with the company culture and the fact that they are not required in responding to the needs of customers.

\section{What kind of knowledge is needed?}

Based on the above, soft regulation possibly supported by indirect legislative regulation emerges as the main means to promote workplace innovation. The main use of legislation lies in the opportunity to impact the operating environment of companies, such as the labour and product markets. However, when attempting to impact matters internal to companies with the aim of improving operational performance and QWL, the significance of soft regulation is highlighted.

Examples of direct forms of soft regulation stated earlier were advisory and consulting services, benchmarking tools, and grants and subsidies to companies. Development programmes are a widely used approach, which is based on soft regulation, making use of the above means, in facilitating workplace change and innovation. By 'programme', we mean fixed-term institutionalized activity in which, first, development is guided by a shared framework which applies to several companies at the same time while; secondly, the content of the framework has been agreed by management and personnel of the companies in question, together with main stakeholder groups such as central government, the social partners and researchers, consultants and other experts; and thirdly, the companies involved engage in exchange of information, interaction and cooperation (Alasoini 2008). Even though there is wide evidence of publically-funded development programmes to promote productivity and QWL in different countries, the programmes and the analyses performed on them (e.g. Alasoini 2009; Brödner \& Latniak 2003; Business Decisions Limited 2000; Den Hertog \& Schröder 1989) rarely contain detailed assessment of the type of knowledge the development work performed in the programmes and their projects was based on. A partial exception to the rule is Naschold's (1994) seminal work, in which he traces 'best practices' of national strategies in developing workplaces.

In workplace development, it is possible to make a distinction between three elementary types of knowledge that is needed for designing and implementing programmes of the kind described above. In order to bring about improvements in operational performance and QWL through projects, knowledge on both new workable designs and collaborative ways to construct them at workplace level is required. Design knowledge is needed in exploring the existing and the possible future states and features of companies by mirroring them to different theories or models of design. The means used in this can include various 'good practices' concerning areas such as work process, work organization, working methods and the work environment and analyses performed on the development possibilities of companies. Process knowledge is needed to help companies find proper ways of implementing participatory processes of change on the basis of theories or models of change and development intervention. In addition to micro-level changes, workplace development programmes aim to bring about changes in working life on a broader front, too. Therefore, dissemination knowledge is needed for the purpose of supporting the transfer and diffusion of experiences of new designs and 
processes of change and intervention for the benefit of actors who did not themselves participate in the projects. In the following, a more detailed description of each knowledge type is given.

\section{Design knowledge}

The implementers of programmes and projects must have an insight of the type of factors that should be influenced in order to achieve the desired changes in the company. Three main approaches can be distinguished here (Delery \& Doty 1996). In the following, we provide a short characterisation of each and consider their usefulness for workplace development.

Firstly, there are views according to which it is possible to find certain organizational and HRM practices and underlying principles that can be applied in order to promote operational performance and QWL in a more or less generally applicable way. This type of approach could be called universalistic. For example, Appelbaum et al. (2000) distinguish three sets of practices (or principles) that lead to high-performance working: those that ensure that personnel has sufficient skills and competencies, those that motivate personnel by providing them appropriate incentives, and those that support personnel's opportunities for substantive participation in work-related matters. In addition to ability, motivation and opportunities for participation, Guest (2006) emphasizes the significance of practices that are associated with high commitment of personnel to the organization.

The contingency approach, in contrast, starts out with the assumption that there are no unique, generally applicable organizational and HRM principles or practices, and instead what is relevant is how compatible they are with the operating environment of companies and, in particular, with their basic business strategy choices. According to the contingency approach, several 'good' or 'best practices' can be identified, and their functionality will then depend on this compatibility (e.g. Boxall \& Purcell 2003; Gual \& Ricart 2001).

A third approach is the configurational approach. According to this approach, attention must be paid, in addition to the external fit between practices and strategy choices as in the case of the contingency approach, to the mutual internal fit of these practices. The practices produce more or less unique combinations, which can be called configurations. The functioning of the configurations depends on the complementarity of their different elements. Complementarity can be said to exist between two elements when doing more of one thing increases the returns to doing more of the other (Roberts $2004,34)$. The idea of complementarity leads to the principle of supermodularity, i.e. the benefit produced by a certain combination of practices is bigger than the total benefit that might accrue from adopting each individual practice separately. The configurational approach differs from the other two approaches dealt with above, particularly in its more holistic view. Another difference is that in it, it is assumed that the maximum performance level can be attained through many different combinations of practices (the principle of equifinality), rather than just some specific combination. On an epistemological level, the configurational approach may be seen to give more emphasis to the significance of 'local' knowledge of the actors in searching for workable designs at the expense of descriptive or analytical models. 
The approaches are thus based on different assumptions. They should not, however, be perceived as wholly separate or mutually exclusive but may also serve to complement one another. The usefulness of the approaches for workplace development can be considered through the categorisation presented in Table 2.

Table 2 Three approaches to design knowledge and their usefulness in development activities

\begin{tabular}{ll}
\hline Approach & Usefulness \\
\hline $\begin{array}{l}\text { Universalistic: 'good' or 'best' organizational } \\
\text { and HRM principles/practices }\end{array}$ & $\begin{array}{l}\text { Principles: useful when setting goals for } \\
\text { programmes and general criteria for projects } \\
\text { Practices: applicability depends on context }\end{array}$ \\
\hline $\begin{array}{l}\text { Contingency: external fit between company } \\
\text { strategy, and organizational and HRM }\end{array}$ & $\begin{array}{l}\text { Strategy-based view: problematic: ethically } \\
\text { principles/practices }\end{array}$ \\
\hline $\begin{array}{l}\text { Configurational: internal fit between } \\
\text { organizational and HRM principles/practices } \\
\text { (and external fit to company strategy) }\end{array}$ & $\begin{array}{l}\text { Principles: offers few principles that can be } \\
\text { generalized more widely } \\
\text { Practices: useful when creating functional }\end{array}$ \\
& organization-specific solutions \\
\hline
\end{tabular}

The usefulness of the universalistic approach derives mainly from the setting of goals for programmes and criteria for projects. It is possible to formulate some general principles that should be accounted for in workplace development, even if the actual practices created based on these principles would vary according to situation. These could include principles that promote a high level of skills and competences, and strong motivation and commitment among personnel as well as good opportunities for participation in the workplace and for influencing one's own work. Another such principle could be that the management and personnel have the capacity and willingness to collaborate in the pursuit of common goals. Yet another could be the capacity of the company to make use of various kinds of external expertise and different networks of experts to support its operations and development.

The utilisation of the contingency approach in workplace development is a less straight-forward matter. The traditional strategy-driven conception, according to which strategies and markets ultimately define the resources required from a company and thereby also determine the most appropriate organizational and HRM practices, will, when applied too rigidly, lead to a situation that is ethically problematic. This means that different practices would need to be recommended to different companies, and the impacts on QWL would most likely also be vastly different. One way to avoid this would be to concentrate exclusively on companies that apply strategies 'appropriate' for the purposes of promoting QWL. In both of the cases described, the actual consequence could be increased segmentation of working life and workforce and even the promotion of inequalities.

In a more recent, resource-driven conception, the contingency approach has been turned on its head. According to it, companies are able to expand their strategic leeway and positioning in their own operating environment by purposefully developing their resources. The development of resources, such as the skills and competences of personnel, 
improves the innovative capacity of the company, which increases its opportunities to choose between alternative operating strategies and liberate itself from the need to seek purely cost-based competitive advantage (e.g. Bessant 2003; Dabhilkar \& Bengtsson 2007). Resource-driven contingency thinking is thus well-suited as a starting point for workplace development.

The usefulness of the configurational approach lies primarily in the designing of project-level solutions. The approach helps us understand, for example, why companies are often unwilling to try out solutions that have proved useful elsewhere or why these solutions do not work in the expected way when transferred from one environment to another but may, in fact, sometimes lead to the exacerbation of the situation, rather than improvement (Pettigrew et al. 2003; Roberts 2004). The approach can also help to understand why certain combinations of different practices may have qualities that promote or reduce operational performance or QWL. The main limitation of this approach lies in its poor capacity to produce straight-forward knowledge that can be directly applied in other contexts. A view of organizational change which is based on the configurational approach needs to be supported with supplementary views, i.e. views that combine its holistic and systemic perspective with a developed methodology to analyse mutual incompatibilities between practices as starting points for employee-involving development initiatives, such as developmental work research (e.g. Engeström 2005).

\section{Process knowledge}

Rather than completely separate categories of knowledge, design and process knowledge are, in fact, interconnected in many ways. Different approaches used in workplace development may, however, stress them and their significance in different ways. It is thus possible to talk about design-oriented and process-oriented approaches (Buhanist 2000).

A traditional way to differentiate between approaches in relation to process knowledge is to distinguish between approaches that are expert-driven or promote personnel participation (participatory). In the former, the change process is guided by a model created by management and/or consultants or researchers. The role of personnel is mostly limited to the adjustment of certain details. In the latter, the personnel is a genuine, independent actor in the planning and implementation of changes.

Another distinction focuses on whether the approaches would be best described as monologue-oriented or dialogue-oriented. The expert-driven approach is largely based on monologue: the source of all planning and ideas for change is expert knowledge alone. The simple fact of personnel participation does not, however, mean that the approach could be described as dialogue-oriented. If management and personnel have their own separate objectives and requirements, the solutions achieved may not amount to more than compromises adhering to the traditional logic of negotiation. A dialogueoriented approach means that in their mutual interaction, the parties are prepared to genuinely listen and understand each other and consequently also prepared to critically analyse their own starting points and adjust them (e.g. Gustavsen 1992; Lehtonen \& Kalliola 2008). This means that the interaction between the parties can generate solutions that are genuinely more evolved than would be possible through the independent effort of any one party (Table 3 ). 
Table 3 Three different operative logics when implementing changes

\begin{tabular}{lll}
\hline Approach & $\begin{array}{l}\text { Interaction between management } \\
\text { and personnel }\end{array}$ & Logic guiding the solutions \\
\hline Expert-driven & Monologue-oriented & Dictation \\
\hline $\begin{array}{l}\text { Involves genuine participation } \\
\text { from personnel }\end{array}$ & Monologue-oriented & Negotiation \\
\hline $\begin{array}{l}\text { Involves genuine participation } \\
\text { from personnel }\end{array}$ & Dialogue-oriented & Co-creation \\
\hline
\end{tabular}

In dialogue-oriented approaches, the change process is typically conceived of in the form of a cycle. This means that even though the process can be divided into certain logical and consecutive stages, it also involves feedback reactions and redefinitions. The change process is also not understood as a group of independent and one-off events, but different cycles are layered on top of one another and succeed one another. The importance of a dialogue-orientation in different approaches has been advocated based on reasons other than its instrumental value. Dialogue-orientation and the broad-based participation required by it have also been considered humane or democratic values in themselves like in participatory action research (Gustavsen 1992; Lehtonen \& Kalliola 2008). In developmental work research, dialogue and participation in the form of 'multi-voicedness' have been considered significant also due to the potential for expansive learning inherent in it, i.e. learning that leads to a more developed conceptualization of the object and motive of one's activity (Engeström 2005).

The generation of workplace innovations typically requires a dialogue-oriented approach. A constructive view on workplace innovation adopted in this paper emphasizes the 'local' and 're-inventive' nature of innovation, which means that the concept should not be equated with, for example, the adoption of any ready-made set of 'highperformance work practices'. Companies can model their workplace innovations on those implemented elsewhere, but refining them into renewals that improve operational performance and QWL in their own operations often requires a vast amount of what can be described as re-inventing the innovation at the local level. Generally speaking, the degree to which an innovation is re-invented, i.e. modified by the adopter as it diffuses, is positively related to the innovation's sustainability (Rogers 2003, 429).

According to the constructive view, workplace innovations should be studied as threedimensional phenomena (Table 4). Their content describes the features comprised in the new practice. The process describes how the new practice is created and who have participated in its creation. Has a wide range of information sources and diverse knowhow, for example, been utilized in creating the new practice? The third dimension refers to the context, i.e. the purpose for which the new practice has been created. For example, will a shared view of the purpose of the new practice arise between the relevant actors?

In order to genuinely promote the development of working life and workplace innovations, design knowledge thus requires process knowledge to support it. Process knowledge helps to make use of versatile competence in the implementation of changes and to create shared understanding between the actors on the necessity of changes and the new solutions developed. Direct forms of participation usually form the main chan- 
Table 4 The three dimensions of workplace innovation

\begin{tabular}{lll}
\hline Content (What?) & $\Rightarrow \quad \begin{array}{l}\text { The new practice contains some properties that enable } \\
\text { improvements to the current state of affairs. }\end{array}$ \\
\hline Process (How?) & $\begin{array}{l}\text { The new practice has been created in a process which, } \\
\text { through wide participation of the personnel and, where } \\
\text { necessary, of customers, has enabled broad-based } \\
\text { utilization of expertise in designing and implementing } \\
\text { solutions. }\end{array}$ \\
\hline Context (Why?) & $\begin{array}{l}\text { The new practice has been created in a context which, } \\
\text { through extensive interaction between management, } \\
\text { personnel and, where necessary, customers, has } \\
\text { enabled the emergence of a shared understanding of } \\
\text { the bases of solutions. }\end{array}$ \\
\hline
\end{tabular}

Source: Inspired by Martens et al. (2006) and Pettigrew (1987).

nel of involvement for most employees during the process of change. The more ambitious, complex and unpredictable the change is by its aims and possible outcomes, the more important it is to back up direct employee involvement with supplementary representative forms of participation (Nielsen \& Lundvall 2003).

Recent innovation research has placed increasing emphasis on the significance of organizations' external network relations to innovations. One of the best-known contributions to this is the distinction made by Chesbrough (2006) between the traditional closed and a more recent open model. Despite its name, Chesbrough's model of open innovation becomes less open when the ownership of information is considered. A number of other new innovation models contain much more radical perceptions with view to openness and the sharing of information (e.g. Howe 2008; Lee \& Cole 2003; Von Hippel 2005).

The utilisation of open and distributed networks offers a vast amount of possibilities for workplace development as a new perspective to process knowledge. By bringing together companies, communities and individuals interested in similar development questions or even engaged in similar development activities, it is possible to generate new solutions and promote interactive learning. In fact, the development of workplace innovations often offers even better opportunities for the application of the concept of open and dispersed innovations than purely technological innovation activities, as the issues focused on are less often deemed confidential and their direct copying is typically more difficult.

\section{Dissemination knowledge}

According to the traditional linear innovation model, an innovation is a one-directional process. The linear model has been previously used mainly to describe the birth of technological product innovations. When applied to workplace development and workplace innovations, the linear model can be described as a three-stage process (creation - transfer - reception). Solutions which prove to be useful are created in a local context; then 
these, or some elements of these, are transferred into another context; and, finally, they are adopted in one form or another in a new context.

It can be assumed that the factors affecting the diffusion of workplace innovations are similar to those impacting the diffusion of innovations in general. Rogers (2003) has identified five principal factors affecting the diffusion. These are: the relative advantage of the innovation; its compatibility (i.e. the degree to which an innovation is perceived as consistent with the existing values, past experiences and needs of potential adopters); its simplicity (i.e. the degree to which an innovation is perceived to be relatively easy to understand and use); its trialability (i.e. the degree to which an innovation may be experimented with on a limited basis); and its observability (i.e. the degree to which the results of an innovation are visible to others). On general note, it can be claimed that in the light of the above five criteria, the diffusion of workplace innovations according to the linear model poses a number of challenges. Also results from several workplace development programmes show that ideas that have proved functional in one company typically are not easily diffused to other companies (e.g. Arnkil 2008; Gustavsen 2008; Riegler 2008).

We can refer to the existence of a chasm between the first-order and generative results of a programme (Alasoini 2006; 2008). First-order results mean changes immediately due to projects undertaken in the companies participating in the projects. In programmes promoting workplace change and innovation, typical first-order results are improvements in product quality, process flow, the design and organization of work, the work environment and job satisfaction. Generative results show how the results of projects supported through the programme benefit other parties besides those directly involved. However, generative results do not necessarily - and in workplace development, not even primarily - involve ready-made 'best practices' that can be transposed from one context to another; rather, they involve the production and dissemination of generative ideas which can become sources of inspiration or encouragement to actors outside the project.

Table 5 contains five different strategies that can be applied to improving the programme's capability to produce generative results. The strategies are different in terms of the methods they utilise when seeking to improve various phases of the processes leading to innovation (creation - transfer - reception), and in the manner in which they define the phases' temporal relationship.

The first strategy is based on the idea of deploying various means of transfer, for example training, mentoring, marketing, consultancy, seminars, publications, data banks, etc., more efficiently within programmes. The second alternative is to shift programme resources from the 'over-resourced' innovation creation stage (i.e. the stage at which 'good practices' are created in demonstration projects) to the 'under-resourced' reception stage. Thirdly, it is possible to improve the capacity of programmes to provide generative results, by enhancing the knowledge provided by demonstration projects. This is achieved through a more rigorous analysis of causal mechanisms and the interdependencies between different phenomena. Such a process applies to the relationships between the new (good) organizational and HRM practices and the desired outcomes, as well as between the organizational and HRM practices themselves (e.g. Hesketh \& Fleetwood 2006; Martens et al. 2006). A shared feature of all three strategies is that they continue to be based on the idea of temporally separated phases of creation, transfer and reception. 
Table 5 Different strategies for improving the capacity of programmes to produce generative results

\begin{tabular}{llll}
\hline Strategy & $\begin{array}{l}\text { Relation between creation, } \\
\text { transfer and reception }\end{array}$ & $\begin{array}{l}\text { How to improve } \\
\text { creation? }\end{array}$ & $\begin{array}{l}\text { How to improve transfer } \\
\text { and reception? }\end{array}$ \\
\hline $\begin{array}{l}\text { More efficient use of } \\
\text { means of transfer }\end{array}$ & Sequential & No change & $\begin{array}{l}\text { Selective and tailor-made } \\
\text { use of means for targeted } \\
\text { groups of potential } \\
\text { adopters }\end{array}$ \\
\hline $\begin{array}{l}\text { Shift of resources } \\
\text { from creation to } \\
\text { reception }\end{array}$ & Sequential & $\begin{array}{l}\text { More focused } \\
\text { approach }\end{array}$ & $\begin{array}{l}\text { Increased support for } \\
\text { 'second wave' adopters }\end{array}$ \\
\hline $\begin{array}{l}\text { Elaborating causal } \\
\text { mechanisms of } \\
\text { demonstration }\end{array}$ & Sequential & $\begin{array}{l}\text { Greater research } \\
\text { input }\end{array}$ & $\begin{array}{l}\text { More convincing evidence- } \\
\text { based argumentation }\end{array}$ \\
\hline $\begin{array}{l}\text { Enriching knowledge } \\
\text { from demonstration }\end{array}$ & Partly overlapping & $\begin{array}{l}\text { Broader base for } \\
\text { validation }\end{array}$ & $\begin{array}{l}\text { Bridging the social and } \\
\text { cultural gap between } \\
\text { creation and reception }\end{array}$ \\
\hline $\begin{array}{l}\text { Using learning } \\
\text { networks }\end{array}$ & Parallel & $\begin{array}{l}\text { Mutual learning within learning network, through } \\
\text { interaction and co-creation, improves creation } \\
\text { and forms a broader and more valid basis for } \\
\text { transfer }\end{array}$ & \\
\hline
\end{tabular}

The fourth strategy, in turn, is based on the idea of enriching the knowledge provided by demonstration projects, by rendering this knowledge more interactive and easier to adopt for other workplaces. Within the programme, good practices including a lot of 'flesh and blood', i.e. including emotional aspects and examined from multiple perspectives, are substituted for traditional 'passive' and formal presentations, case banks or other kinds of description. The interactive nature of good practices is enhanced, for example, by using narrative methods or those which produce different kinds of emotional experiences. Here, particular attention is paid to the distinct learning styles of different potential adopters (Arnkil 2008). The fourth strategy represents a partial departure from the viewpoint that creation and reception are two totally separate phases of the innovation process.

The fifth strategy for creating generative results, i.e. utilising learning networks, corresponds to an even more radical blurring of the tendency to think in phases. In utilising learning networks, the idea is to bring together, within programmes as well as individual projects, several actors who share an interest in sufficiently similar development issues, but who still have a sufficiently broad diversity of expertise. Several parallel experiments are ongoing at the same time, learning from each other by exchanging information or joining forces to achieve something together. The production of generative results is thus an in-built objective in making use of learning networks. Such networks can function within the context of a programme, not just as a forum for the exchange of information between project participants, but also as an intermediate-level structure which might facilitate the broader exchange of information, both within programmes and beyond their 
boundaries. In recent years, the Nordic countries have formed the most interesting field of experiments in the utilisation of such networks in the European context, not only in the distribution of information about new organizational and HRM practices or other solutions but also in the creation of new knowledge regarding these practices (Alasoini et al. 2011; Ekman et al. 2011).

\section{How to promote the productivity of work and the quality of working life simultaneously?}

As stated earlier, it is socio-politically worthwhile to look for means that impact the productivity of work and the amount of labour input simultaneously. It was also stated that the amount of labour input can be influenced through improving QWL. However, increasing productivity on the level of the national economy does not mean that the primary development target on the level of the individual work organization would also have to be the productivity of work. Improvement in operational performance, such as the quality of products and services, customer service or process flow, may have positive macro-level effects that are reflected in work productivity. Rather than take the narrow notion of work productivity, the target of workplace development on the level of the work organization thus consists of the simultaneous improvement of the broader concept of operational performance and QWL.

Operational performance and QWL are intertwined in many ways on the level of the work organization. A central point of departure for the TYKE and TYKES programmes in Finland has been that problems in both operational performance and QWL can be analysed as reflections of deficiencies in the overall mode of operation prevalent in the organization and that problems in both areas could be tackled with similar means (Alasoini et al. 2005). An analysis of 409 concluded development projects that were funded by the programmes between 1996 and 2005 shows that in more than $70 \%$ of the cases simultaneous improvements in operational performance and QWL at work organization level could be found (Ramstad 2009). The analysis also found a clear positive association between improvements in these two areas. The main conditioning factors for projects that had made simultaneous progress in performance and QWL were employees' participation in the planning and implementation of the projects, close cooperation between management and personnel during the implementation phase, tailor-made development methods used by the consultants or researchers working for the projects, and utilization of external networks in support of the project.

To demonstrate what was stated above and how in concrete terms simultaneous improvements in performance and QWL have been achieved in the projects, we make use of a distinction made by Virkkunen et al. (2007) between two different approaches applied in workplace development. In the following, these are termed process-driven development and concept-driven development. 'Process-driven' here refers to an orientation towards a set of activities that produce value to a customer, and should not be confused with 'process-oriented approaches to development' as opposed to 'design-oriented approaches' (see above).

Process-driven development is based on the notion that work organizations can be described as a collection of operational processes. As the traditional way to design and describe organizations has been mainly based on functions, it has often been the case 
that not enough attention has been paid to the designing and development of processes. In the operations of organizations, this has led to breaches in communication, disturbances, quality deficiencies, waste, overlapping or extra work, etc. All of these decrease operational performance and reduce QWL, for example by increasing work load, reducing employees' discretion over the work speed and creating tensions and conflicts within the work organization. By identifying core processes and performing participatory modelling on them, analysing their problem areas and finding new solutions for these problem areas, it is often possible and even relatively easy to find sustainable solutions for the simultaneous improvement of operational performance and QWL.

In recent years, the amount of interest in process-driven development has been increased by greater demands regarding the quality, flexibility and customer-specific tailoring of the products and services of companies and public workplaces. In the projects carried out in the TYKE and TYKES programmes, work processes have constituted the most common target of development. The development of work processes has often resulted in changes in the organization of work, skills and competence requirements, leadership and management as well as in internal and external cooperation relationships of the organization.

Even though process-driven development has contained - and will continue to do so in the future - significant opportunities to improve the operational performance of organizations and QWL, process-driven development is, due to the deep-rooted cultural impact of Taylorism on management thinking, often guided by a relatively static perception of the needs of the customers and of the products and services provided. Sometimes it is necessary to place the entire operational concept of the organization under critical inspection. Concept-driven development is based on a notion according to which work organizations can be viewed as functional systems. The pace of change varies between the different parts of the system, as they are under the impact of different pressures to change. The differences in timing cause functional disturbances and compatibility problems, which reduce both operational performance and QWL (Launis \& Pihlaja 2007). In situations where the different parts and processes of an organization continue to evolve guided by different historically formed concepts, a mere critical assessment of processes may no longer be sufficient. In this situation, a broader approach to development is necessary that aims at locating an entirely new guiding concept. Locating a new operational concept and putting it into practice usually calls for redefinition of existing organizational boundaries and the emergence of new cooperative relationships.

Concept-driven development may also lead to a rather radical redefinition of the products and services and customer relationships of organizations. It is likely that this type of approach to development will be required more and more often in the future, as operating environments become increasingly volatile. Indications that the need for concept-level development approach is increasing in significance can be seen for example in the Finnish metal industry, retail trade or hotel and restaurant business already from several years ago; companies compete increasingly with comprehensive conceptbased offerings, instead of individual products or services. The same line of development is taking place in publically-funded services. For example, efficient response to the double pressure that is expected to impact the field of social and welfare services in the years to come in Finland - simultaneous increase in demand and decrease in the supply of workforce - may not be possible with process-level development alone (Virkkunen et al. 2007). 
It is through concept-level development that the new, broad-based view of innovation activity will be probably best able to display its strengths in the future. Conceptlevel development usually calls for holistic approach to development, which at the same covers new business management, technological, service and work organizational solutions, i.e. systemic innovation; a matter that is in the heart of the new broad-based innovation policy in Finland.

\section{Conclusion}

This paper has highlighted the interconnections between workplace development and the prerequisites of both economic growth and the preservation of the Finnish welfare state. It has aimed to explain why, in addition to the productivity of work, improving the quality of working life should feature as an increasingly important aim in the innovation policy of the future. The article presents an elaborate argumentation in favour of the kind of broad-based innovation policy, which is based on mutually-supporting relationship between economic and human and social aspects of work activity. At the centre of workplace development are the working people, their work activity and the organizational and communal forms that serve to bind these activities together. It is through this perspective that workplace development adds value to other innovation activity and interacts with other perspectives contained by the new and broadened innovation policy.

Secondly, this paper examines what kind of knowledge is needed for designers and implementers of workplace development programmes and projects in order to reinforce and legitimize their position in the new innovation policy approach. Based on a constructive view on workplaces innovation adopted in the article, the author makes a distinction between three types of knowledge: knowledge on new workable designs, knowledge on collaborative ways to construct or re-invent the designs at work organization level, and knowledge on how to produce and disseminate knowledge on workplace innovations as generative ideas for the use of actors outside the project. Besides Naschold's (1994) seminal work, there exist, so far, surprisingly few detailed policy-oriented analyses where the focus has been on the knowledge infrastructure of workplace development programmes and projects.

Finally, the macro-level analyses on the role of workplace development and QWL in the overall innovation policy context and the meso-level analyses on the types of knowledge needed in workplace development presented in this paper, are supplemented with a look at micro-level conditions for successful projects. It is argued that especially the principles of concept-driven development are well in line with basic premises of the new broad-based innovation policy approach.

\section{References}

Aho, E. et al. (2008) Proposal for Finland's National Innovation Strategy. Helsinki: Ministry of Employment and the Economy.

Alasoini, T. (2006) In Search of Generative Results: New Generation of Programmes to Develop Work Organization. Economic and Industrial Democracy, 27(1), 9-37. 
Alasoini, T. (2008) Building Better Programmes: Learning Networks in the Promotion of Workplace Innovation. International Journal of Action Research, 4(1+2), 62-89.

Alasoini, T. (2009) Strategies to Promote Workplace Innovation: A Comparative Analysis of Nine National and Regional Approaches. Economic and Industrial Democracy, 30(4), 614-642.

Alasoini, T., Lahtonen, M., Rouhiainen, N., Sweins, C., Hulkko-Nyman, K. \& Spangar, T. (eds.) (2011) Linking Theory and Practice: Learning Networks at the Service of Workplace Innovation. Reports of the Finnish Workplace Development Programme 75. Helsinki: Tekes.

Alasoini, T., Ramstad, E. \& Rouhiainen, N. (2005) The Finnish Workplace Development Programme as an Expanding Activity: Results, Challenges, Opportunities. Reports of the Finnish Workplace Development Programme 47. Helsinki: Ministry of Labour.

Appelbaum, E., Bailey, T., Berg, P. \& Kalleberg, A.L. (2000) Manufacturing Advantage: Why High-Performance Work Systems Pay Off. Ithaca, NY: Cornell University Press.

Arnkil, R. (2008) In Search of Missing Links in Disseminating Good Practice - Experiences of a Work Reform Programme in Finland. International Journal of Action Research, $4(1+2), 39-61$.

Bessant, J. (2003) High-Involvement Innovation: Building and Sustaining Competitive Advantage through Continuous Change. Chichester: John Wiley.

Boxall, P. \& Purcell, J. (2003) Strategy and Human Resource Management. Houndmills: Palgrave Macmillan.

Bresnahan, T.F., Brynjolfsson, E. \& Hitt, L.M. (2002) Information Technology, Workplace Organization, and the Demand for Skilled Labor: Firm-Level Evidence. Quarterly Journal of Economics, 117(1), 339-376.

Brödner, P. \& Latniak, E. (2003) Sources of Innovation and Competitiveness: National Programmes Supporting the Development of Work Organisation. Concepts and Transformation, 8(2), 179-211.

Buhanist, P. (2000) Organisational Change, Development Efforts and Action Research. Report No 12. Espoo: Helsinki University of Technology, Industrial Management and Work and Organizational Psychology.

Business Decisions Limited (2000) Government Support Programmes for New Forms of Work Organisation: A Report for DG Employment \& Social Affairs. Luxembourg: Office for Official Publications of the European Communities.

Business Decisions Limited (2002) New Forms of Work Organisation: The Obstacles to Wider Diffusion. Brussels: European Commission, DG for Employment, Industrial Relations and Social Affairs.

Chesbrough, H. (2006) Open Innovation: The New Imperative for Creating and Profiting from Technology. Boston: Harvard Business School Press.

Dabhilkar, M. \& Bengtsson, L. (2007) Continuous Improvement Capability in the Swedish Engineering Industry. International Journal of Technology Management, 37(3/4), 272-289.

Delery, J.E. \& Doty, D.H. (1996) Modes of Theorizing in Strategic Human Resource Management: Tests of Universalistic, Contingency, and Configurational Performance Predictions. Academy of Management Journal, 39(4), 802-835.

Den Hertog, J.F. \& Schröder, P. (1989) Social Research for Technological Change: Lessons from National Programmes in Europe and North America. MERIT 89-028. Maastricht: University of Limburg.

Ekman, M., Gustavsen, B., Asheim, B.T. \& Pålshaugen, Ø. (eds.) (2011) Learning Regional Innovation: Scandinavian Models. Houndmills: Palgrave Macmillan.

Engeström, Y. (2005) Developmental Work Research: Expanding Activity Theory in Practice. Berlin: Lehmanns Media. 
Gergils, H. (2005) Dynamic Innovation Systems in the Nordic Countries? A Summary Analysis and Assessment. Stockholm: SNS förlag.

Gual, J. \& Ricart, J.E. (eds.) (2001) Strategy, Organization and the Changing Nature of Work. Cheltenham: Edward Elgar.

Guest, D. (2006) High-Performance Working: HRM and Performance, in Porter, S. \& Campbell, M. (eds.) Skills and Economic Performance. London: Sector Skills Development Agency, 173-195.

Gustavsen, B. (1992) Dialogue and Development: Theory of Communication, Action Research and the Restructuring of Working Life. Assen: Van Gorcum.

Gustavsen, B. (2007) Work Organization and the 'Scandinavian Model'. Economic and Industrial Democracy, 28(4), 650-671.

Gustavsen, B. (2008) Learning from Workplace Development Initiatives: External Evaluations versus Internal Understandings. International Journal of Action Research, 4(1+2), $15-38$.

Hesketh, A. \& Fleetwood, S. (2006) Beyond Measuring the Human Resources ManagementOrganizational Performance Link: Applying Critical Realist Meta-Theory. Organization, 13(5), 677-699.

Howe, J. (2008) Crowdsourcing: How the Power of the Crowd Is Driving the Future of Business. New York: Random House.

Jalava, J. \& Pohjola, M. (2008) The Roles of Electricity and ICT in Economic Growth: Case Finland. Explorations in Economic History, 45(3), 270-287.

Kauppinen, T., Hanhela, R., Kandolin, I., Karjalainen, A., Kasvio, A., Perkiö-Mäkelä, K., Priha, E., Toikkanen, J. \& Viluksela, M. (eds.) (2010) Työ ja terveys Suomessa 2009. Helsinki: Työterveyslaitos.

Launis, K. \& Pihlaja, J. (2007) Changes in Production Concepts Emphasize Problems in Work-Related Well-Being. Safety Science, 45(5), 603-619.

Laursen, K. \& Foss, N.J. (2003) New Human Resource Management Practices, Complementaries and the Impact on Innovation Performance. Cambridge Journal of Economics, 27(2), 243-263.

Lee, G.K. \& Cole, R.E. (2003) From a Firm-Based to a Community-Based Model of Knowledge Creation: The Case of the Linux Kernel Development. Organization Science, 14(6), 633-649.

Lehto, A.-M. \& Sutela, H. (2009) Three Decades of Working Conditions: Findings of Finnish Quality of Work Life Surveys 1977-2008. Helsinki: Statistics Finland.

Lehtonen, J. \& Kalliola, S. (eds.) (2008) Dialogue in Working Life Research and Development in Finland. Frankfurt am Main: Peter Lang.

Martens, H., Lambrechts, F., Manshoven, J. \& Vandenberk, A. (2006) An Organizational Development Approach towards Age Diversity Practices in Belgian Organizations. Ageing International, 31(1), 1-23.

Miettinen, R. (2002) National Innovation System: Scientific Concept or Political Rhetoric. Helsinki: Edita.

Naschold, F. (1994) The Politics and Economics of Workplace Development: A Review of National Programmes, in Kauppinen, T. \& Lahtonen, M. (eds) National Action Research Programmes in the 1990s. Labour Policy Studies 64. Helsinki: Ministry of Labour, 109-155.

Nielsen, P. \& Lundvall, B.-Å. (2003) Innovation, Learning Organizations and Industrial Relations. Working Paper No 03-07. Copenhagen: DRUID.

Pasanen, A. (2010) Tuottavuuskatsaus 2010. Helsinki: Tilastokeskus.

Pettigrew, A.M. (1987) Context and Action in the Transformation of the Firm. Journal of Management Studies, 24(6), 649-670. 
Pettigrew, A.M., Whittington, R., Melin, L., Sánchez-Runde, C., Van den Bosch, F.A.J., Ruigrok, W. \& Numagami, T. (eds.) (2003) Innovative Forms of Organizing: International Perspectives. London: Sage.

Ramstad, E. (2009) Promoting Performance and the Quality of Working Life Simultaneously. International Journal of Productivity and Performance Management, 48(5), 423-436.

Riegler, C.H. (2008) Why Is Learning from National Working Life Programmes Not a Matter of Course? International Journal of Action Research, 4(1+2), 90-113.

Roberts, J. (2004) The Modern Firm: Organizational Design for Performance and Growth. Oxford: Oxford University Press.

Rogers, E.M. (2003) Diffusion of Innovations. Fifth edition. New York: Free Press.

Storrie, D. \& Ward, T. (2007) Restructuring and Employment in the EU: The Impact of Globalisation. Dublin: European Foundation for the Improvement of Living and Working Conditions.

Trubek, D.M. \& Trubek, L.G. (2005) Hard and Soft Law in the Construction of Social Europe: The Role of the Open Method of Co-ordination. European Law Journal, 11(3), 343-364.

Tuominen, E., Takala, M. \& Tuominen, K. (2005) Employers and the Flexible Retirement Age: Employer Views on the Finnish Pension Reform in 2005 and Older Employees' Continued Work. Working Papers 2005:3. Helsinki: Finnish Centre for Pensions.

Veugelers, R. et al. (2009) Evaluation of the Finnish National Innovation System: Policy Report. Helsinki: Ministry of Education - Ministry of Employment and the Economy.

Virkkunen, J., Engeström, Y. \& Miettinen, R. (2007) Sosiaalihuollon kehittämistoiminnan tulevaisuus: projekteista konseptikehittämiseen. Selvityksiä 2007:49. Helsinki: Sosiaalija terveysministeriö.

Von Hippel, E. (2005) Democratizing Innovation. Cambridge, MA: MIT Press.

Whittington, R., Pettigrew, A.M., Peck, S.I., Fenton, E.M. \& Conyon, M. (1999) Change and Complementaries in the New Competitive Landscape: A European Panel Study, 1992-1996. Organization Science, 19(5), 583-600.

Ylöstalo, P. (2005) Työn uudet organisointitavat: käyttö ja käytön esteet yksityisellä ja julkisella sektorilla. Työelämän kehittämisohjelman raportteja 39. Helsinki: Työministeriö. 